\title{
Antiarrhythmic drugs
}

\author{
W S HILLIS, B WHITING
}

Most patients with cardiac arrhythmias require treatment with antiarrhythmic drugs, although recent advances in surgical and electrical techniques are promising.

The ideal antiarrhythmic compound should have:

(1) A wide range of therapeutic activity in both atrial and ventricular arrhythmias.

(2) Parenteral and oral formulations to permit simple dosage schedules.

(3) Pharmacokinetic properties that permit long term prophylactic treatment.

(4) Lack of serious cardiac depressant activity or non-cardiac side effects.

Although the ideal agent has not yet been found, many drugs are now under investigation. Here we review the drugs in current clinical use and refer to other compounds at present under investigation.

The recent development of rapid analytical methods to measure concentrations of antiarrhythmic drugs has allowed therapeutic drug monitoring to play an increasing part in this relatively difficult therapeutic area. Monitoring of drug concentrations is particularly important as the clinical circumstances surrounding cardiac arrhythmias may lead to considerable intersubject and intrasubject differences in pharmacokinetic variables. Variations in absorption, clearance, and volume of distribution may lead to pronounced differences in doseconcentration relations. The plasma concentrations associated with safe and effective antiarrhythmic treatment are usually confined to a narrow range, and this necessitates careful titration of the dose. In addition, efficacy is often difficult to determine if the arrhythmia, although potentially serious, occurs infrequently. The best approach to antiarrhythmic treatment now entails this achievement of target plasma concentrations known to be associated with successful suppression of arrhythmias by dosage adjustments dictated by both concentration monitoring and clinical observation.

\section{Classification of antiarrhythmic agents}

Compounds with antiarrhythmic activity show great variation in their chemical structure and have been classified according to: (1) their anatomical site of action (table I); (2) their clinical range of activity; and (3) their electrophysiological action on isolated cardiac fibres (Vaughan Williams, 1970) (table II).

This third classification allows drugs to be characterised at the preclinical phase of development, but it is of limited clinical value and excludes some agents with antiarrhythmic activity, such as the cardiac glycosides. Four types of basic activity are recognised;

\footnotetext{
Department of Materia Medica, University of Glasgow, Stobhill General Hospital, Glasgow G21 3UW

W S HILLIS, MB, FRCP, senior lecturer

B WHITING, MD, FRCP, reader
}

TABLE I-Site of action of antiarrhythmic compounds

\begin{tabular}{lc}
\hline Sinus node, atrium: & Anomalous pathway : \\
Beta-adrenoceptor blocking agents & Disopyramide \\
Digoxin & Amiodarone \\
Verapamil & Procainamide \\
Procainamide & Quinidine \\
Disopyramide & Ventricle: \\
Amiodarone & Lignocaine \\
Quinidine & Disopyramide \\
Atrioventricular node: & Tocainide \\
Digoxin & Mexiletine \\
Verapamil & Phenytoin \\
Beta-blockers & Procainamide \\
& Quinidine \\
& Amiodarone \\
\hline
\end{tabular}

TABLE II-Classification (Vaughan-Williams) of antiarrhythmic drugs

\begin{tabular}{|c|c|c|c|}
\hline Class I & Class II & Class III & Class IV \\
\hline A $\left\{\begin{array}{l}\text { Quinidine } \\
\text { Procainamide } \\
\text { Disopyramide }\end{array}\right.$ & $\begin{array}{l}\text { Beta-adrenoceptor blocking compounds } \\
\text { Bretylium }\end{array}$ & \multirow{3}{*}{\multicolumn{2}{|c|}{$\begin{array}{l}\text { Amiodarone Verapami } \\
\text { Disopyramide } \\
\text { Sotalol }\end{array}$}} \\
\hline B $\left\{\begin{array}{l}\text { Lignocaine } \\
\text { Mexiletine } \\
\text { Aprinidine } \\
\text { Phenytoin } \\
\text { Tocainide }\end{array}\right.$ & & & \\
\hline C $\left\{\begin{array}{l}\text { Lorcainide } \\
\text { Flecainide }\end{array}\right.$ & & & \\
\hline
\end{tabular}

future developmental agents may require recognition of further classes. In addition, some drugs may have more than one action. Therapeutic success, however, is usually associated with one dominant action.

Class I contains agents with local anaesthetic properties that have membrane stabilising activity. Depolarisation of the cardiac cell membrane is depressed by restricting entry of the fast sodium current (see fig 2 in article on calcium antagonists, 2 April, p 1127). This reduces the maximum rate of rise of phase 0 of the action potential and depresses the rate of phase 4 diastolic depolarisation. These effects tend to reduce spontaneous automaticity. These agents may be further subdivided according to their influence on the duration of the action potential, which may lengthen (group IA), shorten (group IB), or be unaffected (group IC).

Class II agents reduce the potential for arrhythmias to develop in response to catecholamines. Bretylium, for example, blocks the release of sympathetic transmitters. The beta-adrenoceptor antagonists act as competitive antagonists and also block the possible arrhythmogenic effect of cyclic adenosine- $5^{\prime}$-monophosphate.

Class III agents prolong the duration of the action potential with resulting prolongation of the effective refractory period.

Class IV agents inhibit the slow inward calcium mediated current and depress phase 2 and phase 3 of the action potential. These actions have an important influence on the upper and middle parts of the atrioventricular node, and these effects may have particular value in blocking one limb of a re-entry circuit. 


\section{Class I agents}

\section{QUINIDINE}

Quinidine is the parent compound of the class I antiarrhythmic drugs.

\section{Mechanism of action}

Quinidine reduces the maximal rate of depolarisation, depresses spontaneous phase 4 diastolic depolarisation in automatic cells, and, in general, slows conduction through atrial, ventricular, and Purkinje fibres. Its antivagal action may accelerate atrioventricular nodal conduction.

\section{Clinical use}

Quinidine is now of limited clinical use. The lack of an adequate parenteral formulation restricts its use to prophylaxis after cardioversion or after acute administration of lignocaine. It is active against both atrial and ventricular arrhythmias.

\section{Pharmacokinetics}

About $70 \%$ of an oral dose is absorbed from the gut. Peak effects occur within one to three hours. The half life is relatively short (seven hours), and slow release preparations (table III) are now available. The bioavailability of these preparations, however, may be lower than that of non-sustained release products. Antiarrhythmic effects on atrial and ventricular arrhythmias are seen with drug concentrations of $2-5 \mathrm{mg} / \mathrm{l}$. Quinidine is highly protein bound (80-90\%) and is metabolised by hydroxylation. In liver disease the clearance is reduced; half life is increased, protein binding is reduced, and lower total plasma concentrations may be effective. In congestive heart failure the half life is not affected. Quinidine interacts with digoxin and may precipitate digoxin toxicity. The dose of cardiac glycoside accordingly needs to be reduced.

\section{Adverse effects}

Cardiac-Myocardial depression occurs at high plasma concentrations with associated vasodilatation and hypotension. Sinus arrest, sinoatrial block, atrioventricular dissociation, and progressive QRS and QT prolongation may occur. QT prolongation may facilitate the development of re-entry arrhythmias.

Other-Gastrointestinal effects (nausea, vomiting, and diarrhoea) may occur. Cinchonism and hypersensitivity reactions with fever, purpura, thrombocytopenia, and hepatic dysfunction may also occur.

\section{PROCAINAMIDE}

Procainamide exhibits similar electrophysiological properties to those described for quinidine.

\section{Clinical use}

Procainamide is available for both parenteral and oral use and can be effective in the treatment of atrial, junctional, and ventricular arrhythmias. The standard intravenous dose is 100 mg every two minutes, repeating this to a total of $1000 \mathrm{mg}$ over the first hour. Oral treatment may be given as prophylactic therapy.

\section{Pharmacokinetics}

The bioavailability of ingested procainamide is about $85 \%$. Absorption is rapid, peak plasma concentrations occurring about one hour after administration. It is metabolised to an active metabolite, $N$-acetyl procainamide. The rate of metabolism in the population has a bimodal distribution-that is, patients are classified as being fast or slow acetylators. Subjects who exhibit slow acetylation require smaller doses in long term administration. High plasma concentrations of procainamide and $N$ acetyl procainamide may be obtained in renal impairment and cardiac failure. The therapeutic range of the parent compound is 4-10 mg/l; toxic effects are related to the concentration and may start at blood concentrations of $8-10 \mathrm{mg} / \mathrm{l}$. Toxicity is pronounced at concentrations of about $16 \mathrm{mg} / \mathrm{l}$. The half life is about three to five hours, necessitating frequent dosage. Slow release preparations are now available (tables III and IV).

TABLE III-Choice of drugs used in treatment of supraventricular arrhythmia

\begin{tabular}{|c|c|}
\hline Drug (proprietary name) & Dose \\
\hline Verapamil (Cordilox) & $\begin{array}{l}\text { 5-10 mg intravenous bolus over } 30 \mathrm{~s} \text {. } \\
\text { Intravenous infusion } 5-10 \mathrm{mg} / \mathrm{h} \text {, total dose } \\
25-100 \mathrm{mg} \text { daily. Oral dose } 40-120 \mathrm{mg} \text { thrice } \\
\text { daily }\end{array}$ \\
\hline $\begin{array}{l}\text { Beta-blockers: } \\
\text { Practolol (Eraldin) }\end{array}$ & $\begin{array}{l}5 \mathrm{mg} \text { intravenous bolus may be repeated until } \\
20-25 \mathrm{mg} \text { given }\end{array}$ \\
\hline Propranolol (Inderal) & $\begin{array}{l}1 \mathrm{mg} \text { intravenous bolus may be repeated until } \\
5 \mathrm{mg} \text { given }\end{array}$ \\
\hline Metoprolol (Betaloc, Lopressor) & $\begin{array}{l}5 \mathrm{mg} \text { intravenous bolus over } 2 \text { minutes, } \\
\text { repeated at } 5 \text { minute intervals up to total of } \\
15 \mathrm{mg} \text {. Oral dose } 50-100 \mathrm{mg} \text { thrice daily }\end{array}$ \\
\hline $\begin{array}{l}\text { Others: } \\
\text { Digoxin (Lanoxin) }\end{array}$ & $\begin{array}{l}0.5-0.75 \mathrm{mg} \text { intravenously, then maintenance } \\
\text { oral dose of } 0.25 \mathrm{mg} \text { daily. Avoid in Wolf- } \\
\text { Parkinson-White syndrome }\end{array}$ \\
\hline $\begin{array}{l}\text { Disopyramide (Rhythmodan, } \\
\text { Norpace; slow release- } \\
\text { Rhythmodan Retard, } \\
\text { Dirythmin SA) }\end{array}$ & $\begin{array}{l}2 \mathrm{mg} / \mathrm{kg} \text { up to } 150 \mathrm{mg} \text { over } 5 \text { minutes. Repeat } \\
\text { if necessary. Maintenance infusion } 20-30 \\
\mathrm{mg} / \mathrm{h} \text { up to } 800 \mathrm{mg} \text { daily. Oral dose } 300-800 \\
\mathrm{mg} \text { daily. }\end{array}$ \\
\hline Amiodarone (Cordarone $\mathrm{X}$ ) & $\begin{array}{l}3.5 \mathrm{mg} / \mathrm{kg} \text { intravenously over } 5 \text { minutes. Oral } \\
\text { dose } 200 \text { thrice daily for first week then } 200 \\
\text { mg daily }\end{array}$ \\
\hline $\begin{array}{l}\text { Procainamide (Pronestyl; slow } \\
\text { release-Procainamide Durules) }\end{array}$ & $\begin{array}{l}100 \mathrm{mg} \text { intravenous bolus repeated up to } 1 \mathrm{~g} \\
\text { in one hour-maintenance } 2-6 \mathrm{mg} / \mathrm{min} \text {. Oral } \\
\text { dose } 250 \mathrm{mg} \text { every } 4-6 \text { hours or durules } 1.0- \\
1.5 \mathrm{~g} \text { every } 8 \text { hours }\end{array}$ \\
\hline $\begin{array}{l}\text { Quinidine (Quinicardine; slow } \\
\text { release-Kiditard, Kinidin } \\
\text { Durules) }\end{array}$ & $\begin{array}{l}\text { Oral dose } 200-400 \mathrm{mg} 3-4 \text { times daily or slow } \\
\text { release } 500 \mathrm{mg} \text { every } 12 \text { hours }\end{array}$ \\
\hline
\end{tabular}

TABLE IV-Choice of antiarrhythmic drugs for ventricular arrhythmias

\begin{tabular}{|c|c|}
\hline Drug (proprietary name) & Dose \\
\hline Lignocaine (Xylocard, Lidothesin) & $\begin{array}{l}50-100 \mathrm{mg} \text { intravenous bolus; infusion } 1-4 \\
\text { mg/min. Half dose in hepatic and cardiac } \\
\text { failure (see text) }\end{array}$ \\
\hline Mexiletine (Mexitil) & $\begin{array}{l}100-250 \mathrm{mg} \text { over } 5-10 \text { minutes followed by } \\
\text { infusion of } 250 \mathrm{mg} \text { over } 1 \text { hour, } 250 \mathrm{mg} \text { over } \\
2 \text { hours, then } 0.5 \mathrm{mg} / \mathrm{min} \text {. Oral dose } 200-300 \\
\text { mg every } 8 \text { hours }\end{array}$ \\
\hline Disopy & See table III \\
\hline Tocaini & $\begin{array}{l}0.5-0.75 \mathrm{mg} / \mathrm{kg} / \mathrm{min} \text { for } 15 \text { minutes. Oral dose } \\
400-800 \mathrm{mg} \text { then } 400 \mathrm{mg} \text { every } 8 \text { hours }\end{array}$ \\
\hline $\begin{array}{l}\text { Procainamide } \\
\text { Phenytoin (Epanutin) }\end{array}$ & $\begin{array}{l}\text { See table III } \\
50-100 \mathrm{mg} \text { intravenously over } 5 \mathrm{minutes} \text {, repeat } \\
\text { to } 1 \mathrm{~g} \text {. Oral dose } 1 \mathrm{~g} \text { then } 500 \mathrm{mg} \text { for two } \\
\text { days, then } 400 \mathrm{mg} \text { daily }\end{array}$ \\
\hline $\begin{array}{l}\text { Quinidine } \\
\text { Bretylium tosylate (Bretylae) }\end{array}$ & $\begin{array}{l}\text { See table III } \\
5 \mathrm{mg} / \mathrm{kg} \text { intramuscularly repeated every } 6-8 \\
\text { hours at varying sites to avoid minor necrosis }\end{array}$ \\
\hline
\end{tabular}

\section{Adverse effects}

Cardiac-Rapid intravenous administration may lead to reduced cardiac output with hypotension and vasodilatation. PR prolongation may proceed to increased degrees of heart block, and QRS and QT prolongation, particularly in slow acetylators, may also occur.

Other-Long term oral use may be associated with a drug induced lupus erythematosus syndrome with the presence of antinuclear factor. Renal disease rarely occurs, and the effects are usually reversible. 
DISOPYRAMIDE

The electrophysiological properties of disopyramide are similar to those of quinidine.

\section{Clinical use}

Both parenteral and oral preparations are available. The range of activity includes action against both atrial and ventricular arrhythmias, including supraventricular tachycardia and ventricular extrasystoles.

\section{Pharmacokinetics}

Disopyramide is commercially available as both the base compound and the phosphate salt. Bioavailability is about $70-80 \%$. The half life in normal subjects is six to eight hours. The main metabolite is the $N$-dealkylated form of disopyramide. This is excreted by the kidneys, as is most of the parent compound. The dose should be reduced in severe renal failure. The therapeutic range is $2-5 \mathrm{mg} / \mathrm{l}$.

\section{Adverse effects}

Cardiac-Myocardial depression may be clinically important and is related both to the plasma concentration and to the rate of administration of the compound. Use of the drug is therefore contraindicated in heart failure or severe left ventricular dysfunction. QT prolongation related to the drug concentration may also occur, and this may predispose to ventricular arrhythmias with a re-entry mechanism. Sinus node depression may also occur.

Other-Disopyramide has anticholinergic activity, and urinary retention, dry mouth, and blurred vision often occur. Glaucoma may also be precipitated.

\section{LIGNOCAINE}

Lignocaine has typical class I electrophysiological effects.

\section{Clinical use}

Lignocaine remains the first line drug in the treatment of ventricular arrhythmias after acute myocardial infarction and cardiac surgery. After intravenous administration long term treatment is continued with an alternative class I antiarrhythmic given by mouth. After intramuscular injection absorption is erratic, and blood concentrations achieved vary widely according to the haemodynamic state of the patient.

\section{Pharmacokinetics}

Lignocaine is hydrolysed in the gastrointestinal tract and is subject to extensive first pass metabolism in the liver. Adequate blood concentrations are therefore not obtained after oral administration. After intravenous administration the elimination half life is about two hours. Clearance is related to the hepatic blood flow and hepatic function. Clearance is prolonged in the elderly, in cardiac failure, and in hepatic disease, and infusion rates require appropriate adjustment in these cases. Therapeutic efficacy is associated with blood concentrations in the range $1 \cdot 5-5.0 \mathrm{mg} / \mathrm{l}$. Toxicity may occur at a wide range of total blood concentrations and may show considerable overlap with the therapeutic range. The rate of injection may be important in precipitating toxic reactions. The degree of toxicity, however, correlates better with the free drug concentration than with the total plasma concentration. Protein binding may be important in many clinical conditions. The fraction of drug that is free in the plasma may vary from $20 \%$ to $40 \%$ and is determined largely by the concentration of acute phase proteins, notably $\alpha-1$ acid glycoprotein. After myocardial infarction long term infusion leads to progressively increasing plasma concentrations, and a true steady state may not be achieved. Although this may be related to diminished plasma clearance, it may also reflect increasing concentrations of $\alpha-1$ acid glycoprotein. In these patients although total lignocaine concentrations are raised, the free drug concentrations may remain relatively constant. The precise relation between the total and free concentrations of lignocaine and antiarrhythmic activity remains to be clarified.

\section{Adverse effects}

Cardiac-In therapeutic doses lignocaine has little haemodynamic effect. High concentrations may cause bradycardia, hypotension, and even asystole.

Other-Gastrointestinal upset with nausea and vomiting may occur. At concentrations above $5 \mathrm{mg} / \mathrm{l}$ central nervous system side effects, including paraesthesiae, twitching, and grand mal seizures, may occur.

\section{MEXILETINE}

Mexiletine is a primary amine with similar electrophysiological actions to those of lignocaine.

\section{Clinical use}

Mexiletine is effective after intravenous and oral administration in the treatment of ventricular arrhythmias.

\section{Pharmacokinetics}

Peak plasma concentrations are obtained two to four hours after oral administration. Mexiletine is extensively metabolised. The half life is nine to 12 hours in normal volunteers and is prolonged in patients with cardiac disease, particularly those who have sustained an acute myocardial infarction (up to 26 hours). Administration of narcotic analgesics may be associated with reduced absorption. About $10-20 \%$ of an administered dose is excreted unchanged in the urine at normal urinary $\mathrm{pH}$, but renal clearance depends on urinary $\mathrm{pH}$ and may be reduced when the urine is alkalised by antacids. Effective plasma concentrations lie in the range of $0 \cdot 75-2.0 \mathrm{mg} / \mathrm{l}$.

\section{Adverse effects}

Cardiac adverse effects include hypotension, bradycardia, and transient atrioventricular block.

Other-Neurological side effects are common and include $\bar{N}$ tremor, nystagmus, diplopia, dizziness, dysarthria, paraesthesiae, N ataxia, and confusion.

\section{TOCAINIDE}

Tocainide is a primary amine with similar electrophysiological and antiarrhythmic properties to those of lignocaine.

\section{Clinical use}

Tocainide is active after both intravenous and oral administration and may be used to treat acute and chronic ventricular arrhythmias. 


\section{Pharmacokinetics}

Almost all of the tocainide in an oral preparation is absorbed from the gut, and peak plasma concentrations are achieved within 60-90 minutes of ingestion. The elimination half life is around 11-15 hours. Plasma protein binding is about 50\%. At least $40 \%$ of the drug is excreted unchanged in the urine, and the remainder is excreted by hepatic metabolism. Some $25 \%$ is excreted as $N$ carboxy tocainide: other metabolites include glucuronide and lactoxylidide salts, which are inactive. Hepatic clearance is low, which suggests that a substantial first pass effect is unlikely. Antiarrhythmic activity occurs within the plasma concentration range of $6-12 \mathrm{mg} / 1$.

\section{Adverse effects}

Cardiac-No appreciable adverse haemodynamic effects occur at plasma concentrations within the therapeutic range.

Other-Gastrointestinal side effects include anorexia, nausea, vomiting, constipation, and abdominal pain. Effects in the central nervous system are similar to those associated with mexiletine and appear to be related to peak plasma drug concentrations. Rashes and interstitial pulmonary alveolitis have occasionally necessitated withdrawal of the drug.

\section{Investigational agents}

APRINDINE

\section{Mechanism of action}

Aprindine is a class I antiarrhythmic compound with local anaesthetic activity. Electrophysiological studies show slowing of conduction through the bundle of $\mathrm{His}$ with QRS prolongation and increases in the refractory periods of the atria, ventricles, and atrioventricular node.

\section{Clinical use}

Aprindine is effective in both ventricular and supraventricular arrhythmias, but full antiarrhythmic activity may take several days to develop.

\section{Pharmacokinetics}

Aprindine is effective after both oral and intravenous administration: oral bioavailability is high. Relatively long, albeit variable half lives have been reported, of about 22 hours (range 12-66). Protein binding is relatively high at $85-95 \%$. Metabolism occurs by hydroxylation and subsequent glucuronidation. The therapeutic ratio is small. Therapeutic activity occurs within plasma concentrations of $1-3 \mathrm{mg} / \mathrm{l}$, but side effects occur often at concentrations above $2 \mathrm{mg} / \mathrm{l}$.

\section{Adverse effects}

Central nervous system side effects are common, including tremor. Gastrointestinal side effects are less common, and idiosyncratic reactions may affect the liver or bone marrow with cholestasis and agranulocytosis respectively.

\section{LORCAINIDE}

\section{Mechanism of action}

Lorcainide is a class I antiarrhythmic compound with local anaesthetic activity. It seems to be effective in suppressing ventricular ectopic activity.

\section{Pharmacokinetics}

Lorcainide shows a large first pass effect that is apparently dose dependent: bioavailability increases from $4 \%$ with a small single dose to $60 \%$ with a relatively large, $200 \mathrm{mg}$, dose. Its primary metabolite, $N$-dealkylated lorcainide or norlorcainide, has antiarrhythmic activity and a prolonged half life. Side effects include heart block, hypotension, and insomnia.

\section{FLECAINIDE}

\section{Mechanism of action}

Flecainide is similar in activity to lorcainide. Preliminary studies suggest that it is effective in suppressing ventricular arrhythmias.

\section{Pharmacokinetics}

The elimination half life is between 15 and 20 hours.

Note: These drugs require further evaluation before their full clinical value can be assessed, and they remain as investigational agents.

\section{Class II \\ BETA-ADRENOCEPTOR BLOCKING COMPOUNDS}

New beta-adrenoceptor blocking compounds in class II continue to be produced in large numbers. Their antiarrhythmic range is identical despite different properties in regard to cardioselectivity, partial agonist activity, and potency of membrane stabilising activity. The newer drugs in this group will be reviewed in a separate article.

\section{Mechanism of action}

Catecholamine augmented phase 4 depolarisation is blocked. The action potential is shortened, and the functional refractory period of the atrioventricular node is prolonged.

\section{Clinical use}

Beta-adrenoceptor blocking drugs may be used when arrhythmias are associated with high levels of catecholamine production, including arrhythmias induced during anaesthesia.

Their long term use in secondary prevention trials after acute myocardial infarction has been extensively reviewed. While propranolol remains the reference compound, most agents in class II may be given intravenously or by mouth. Practolol given intravenously has been generally used as the first line drug to reduce the ventricular rate in atrial flutter and atrial fibrillation or to cardiovert paroxysmal atrial tachycardia. Long term management has then required the use of alternative agents. Metoprolol and atenolol are increasing in their popularity. Sotalol has additional mild class III activity and may show a wider range of activity.

\section{Adverse effects}

Cardiac-Myocardial depression with hypotension or cardiac failure may occur in patients with little cardiac reserve. Fewer haemodynamic effects may occur with agents with partial agonist activity.

Other-Increased airways obstruction and reduction of peripheral arterial blood flow may occur secondary to blockade of 
beta ${ }_{2}$-receptors by non-selective agents. Beta-blocking agents are therefore contraindicated in patients with obstructive airways or peripheral vascular disease.

\section{Class III}

AMIODARONE

\section{Mechanism of action}

Amiodarone prolongs the duration of the action potential and the effective refractory period in both the atria and ventricles. In higher dosage it may have beta-receptor inhibitory activity and effects such as those with quinidine.

\section{Clinical use}

The full therapeutic range is not yet known. Excellent results have been reported with both supraventricular arrhythmias, particularly if associated with the Wolff-Parkinson-White syndrome, and resistant ventricular arrhythmias. Present use is limited to patients whose arrhythmias are resistant to standard antiarrhythmic compounds.

\section{Pharmacokinetics}

Antiarrhythmic activity is evident after some four to six days of oral treatment. The elimination half life is long (30-45 days) and antiarrhythmic activity may continue for several months after treatment is stopped. Antiarrhythmic efficacy after intravenous administration is variable in its onset, occasionally occurring immediately: this activity does not appear to bear a simple relation to plasma concentration. The amiodarone molecule is deiodinated and blocks the peripheral conversion of thyroxine to triiodothyronine. It leads to a consistent rise in serum reverse triiodothyronine concentrations, and early studies suggest that these concentrations may reflect the efficacy and toxicity of amiodarone.

\section{Adverse effects}

Cardiac-Haemodynamic effects after intravenous administration are usually unimportant, but vasodilatation may occur leading to hypotension. Bradycardia may also occur.

Other-These are common and include corneal micro deposits of yellow brown granules (universal), photosensitisation, skin discoloration with grey or bluish pigmentation, hypothyroidism or hyperthyroidism ( $2-3 \%$ of patients), rise in hepatic enzyme concentrations, interstitial pulmonary infiltration, and proximal muscle weakness. These adverse effects are usually reversed when the drug is withdrawn, but serial eye examinations are recommended during long term use.

\section{Class IV}

VERAPAMIL

\section{Mechanism of action}

Verapamil inhibits slow inward calcium mediated current and is the only agent of this class at present available. The other calcium channel blockers will be reviewed separately in this series.

\section{Clinical use}

The major action of verapamil is exerted on conduction through the atrioventricular node. The ventricular response in atrial fibrillation and flutter is controlled, and cardioversion of paroxysmal re-entrant atrioventricular nodal tachycardia is oftem achieved. Verapamil is the drug of first choice in paroxysma $\mathbb{R}$ supraventricular tachycardia.

\section{Pharmacokinetics}

Verapamil is active when given intravenously or by mouth The elimination half life is three to seven hours. This is pro@ longed in patients with liver disease; the volume of distribution: is increased and clearance diminished. Although absorption fronop the gastrointestinal tract is almost complete, a major first pas effect in the liver reduces systemic bioavailability to under $25 \%$ 든 Renal excretion accounts for $70 \%$ of an oral dose. Norverapamilep an active metabolite, is formed during hepatic metabolism.

\section{Adverse effects}

Cardiac-Myocardial depression may occur in patients witls cardiac failure. Drug interactions may occur with beta-adrenoo ceptor blocking drugs and with digoxin. Concomitant intravenous treatment with beta-blockers should be avoided, and verapamin should be avoided in patients with the sick sinus syndrome of atrioventricular node disease.

Other-Nausea, vomiting, and hypotension may rarely occur

\section{Bibliography}

Brown JE, Shand DG. Therapeutic drug monitoring of antiarthyth

Background review of drug monitoring of antiarrhythmics.
Bryson SM, Whiting B, Lawrence JR. Disopyramide serum and pharmaco logic effect kinetics applied to the assessment of bioavailability. $\mathrm{Br}$ Z Clin Pharmacol 1978;6:409-19.

Emphasises the relation of QT interval to plasma concentrations of disopyramide.

Campbell NPS, Pantridge JF, Adgey AAJ. Long term oral antiarrhythmie therapy with mexiletine. Br Heart $\mathcal{f} 1977 ; 40: 796-801$.

Carliner NH, Fisher ML, Crouthamel WG, Narang PK, Plotnick GD Relation of ventricular premature beat suppression to serum quiniding concentration determined by a new and specific assay. Am Heart कू 1980;100:483-9.

This paper shows atrial and ventricular activity of quinidine.

Gianelly R, Von der Groeben JO, Spivack AP, Harrison DC. Effect of lido caine on ventricular arrhythmias in patients with coronary heart disease$N$ Engl f Med 1967;277:1215-9.

Standard reference for accepted therapeutic range of lignocaine.

Harrison DC, ed. Cardiac arrhythmias: a decade of progress. Boston, Massa chusetts: C K Hall Medical Publishers, 1981.

Review of clinical studies and detailed pharmacology of new anti arrhythmics.

Koch-Weser J, Klein SW. Procainamide dosage schedules, plasma concentra tions and clinical effects. $7 A M A 1971 ; 215: 1454-60$.

Standard reference for efficacy of procainamide and toxicity related to plasma concentrations.

LeLorier J, Grenon D, Latour Y, et al. Pharmacokinetics of lidocaine after prolonged intravenous infusions in uncomplicated myocardial infarction
Ann Intern Med 1977;87:700-2.

Nademanee K, Melmed S, Hendricksen JA. Role of serum $\mathrm{T}_{4}$ and reverse $\mathrm{T}_{P}$ in monitoring antiarrhythmic efficacy and toxicity of amiodarone if resistant arrhythmias. Am $\mathcal{F}$ Cardiol $1981 ; 47: 482-7$.

Interesting use of biochemical marker of activity.

Nademanee K, Singh BN. Advances in antiarrhythmic therapy. $\mathcal{F A M}$ A $1982 \mathrm{~W}$ 247:217-22.

Review of new antiarrhythmics.

Prescott LF, Pottage A, Clements JA. Absorption distribution and eliminfo tion of mexiletine. Postgrad Med f 1978;53, suppl 1:50-5.

Rosenbaum MB, Chiale PA, Halpern MS. Clinical efficacy of amiodarone as an antiarrhythmic drug. Am $\mathcal{F}$ Cardiol 1976;38:934-44.

Review of activity of amiodarone.
Routledge PA, Stargel WW, Wagner GS, Shand DG. Increased alpha-1 $\stackrel{0}{\bar{D}}$ acid glycoprotein and lidocaine disposition in myocardial infarction Ann Intern Med 1980;93:701-4. Singh BN, Elcrodt G, Peter CT. Verapamil : a review of its pharmacologica
properties and therapeutic uses. Drugs $1978 ; 15: 169-203$.

Sokolow $M$, Ball RE. Factors influencing conversion of chronic atriap fibrillation with special reference to serum quinidine concentration Circulation 1956;14:568-83.

Williams EMV. Classification of antiarrhythmic drugs. In: Sandböe $\mathrm{B} \overline{\bar{Q}}$ Flensted-Jensen E, Olesen KH, eds. Symposium on cardiac arrhythmia Södertälje, Sweden: A B Astra, 1970:449-72 